\title{
Genomic and Physiological Comparisons Between Heterotrophic Thiobacilli and Acidiphilium cryptum, Thiobacillus versutus sp. nov., and Thiobacillus acidophilus nom. rev.
}

\author{
ARTHUR P. HARRISON, JR. \\ Division of Biological Sciences, University of Missouri, Columbia, Missouri 65211
}

\begin{abstract}
Acidiphilium cryptum grows in yeast extract media with or without elemental sulfur. The growth rate and the cell yield are not changed by the presence of sulfur, but the $\mathrm{pH}$ of the medium drops slightly when sulfur is present, presumably because of gratuitous sulfur oxidation. No growth occurs with sulfur alone. $A$. cryptum is an obligate chemoorganotroph. Thiobacillus acidophilus grows equally well with either elemental sulfur or glucose as a sole energy source; this organism is a facultative autotroph. Since the name $T$. acidophilus does not appear on the Approved Lists of Bacterial Names, it is revived here, and strain ATCC 27807 is designated the type strain. Thiobacillus perometabolis is considered a subspecies of Thiobacillus intermedius on the basis of close phenotypic similarity and deoxyribonucleic acid homology. Thiobacillus sp. strain A2 is a distinctive mixotroph that shows little deoxyribonucleic acid homology with other species of Thiobacillus. This organism is named Thiobacillus versutus, and strain ATCC 25364 is designated the type strain.
\end{abstract}

Aerobic, mesophilic, nonsporulating, gramnegative, rod-shaped bacteria which utilize elemental sulfur or compounds containing oxidizable sulfur as sources of energy were placed by Vishniac (20) in the genus Thiobacillus Beijerinck. Some of these organisms are obligate chemolithotrophs, and some are acidophilic (i.e., they grow when they are inoculated into media at $\mathrm{pH} \leq 3$ ).

The terms proposed by Rittenberg (15) are used here to denote nutritional categories. Obligate chemolithotrophs acquire their energy from inorganic compounds, and the carbon requirement of these organisms can be met solely with $\mathrm{CO}_{2}$. Mixotrophs can utilize inorganic and organic compounds concurrently. Chemolithotrophic heterotrophs acquire their energy from an inorganic compound but require an organic substance to fulfill their carbon requirement. Obligate chemoorganotrophs acquire their energy from organic compounds.

The non-acidophilic, obligate chemolithotrophs in the genus Thiobacillus include Thiobacillus thioparus and Thiobacillus neapolitanus. These species grow best near a neutral $\mathrm{pH}$ and may grow at $\mathrm{pH}$ values above 9 ; they require inorganic sulfur as a source of energy.

The non-acidophilic mixotrophs include Thiobacillus novellus (a soil organism named and originally described by Starkey $[17,18]$ and further described by Taylor and Hoare [19]) and Thiobacillus sp. strain A2, which was described by Taylor and Hoare (19). These two organisms can grow autotrophically with thiosulfate as the energy source, heterotrophically with organic compounds, or mixotrophically by using inorganic and organic compounds simultaneously. (They have also been referred to as facultative autotrophs.) Thiobacillus intermedius also can grow autotrophically or heterotrophically, but it grows poorly unless both thiosulfate and an organic substance are present (12). Thiobacillus perometabolis, as originally described by London and Rittenberg (13), cannot grow autotrophically, but it does utilize thiosulfate as a source of energy if a suitable organic substance is present to meet its carbon requirement. Under these circumstances this organism grows as a chemolithotrophic heterotroph; it can also grow heterotrophically, with organic substances providing both energy and carbon.

The acidophilic, obligate chemolithotrophs include Thiobacillus thiooxidans and Thiobacillus ferrooxidans. These organisms grow best between $\mathrm{pH} 2$ and $\mathrm{pH} 5$; little if any growth occurs at $\mathrm{pH}$ 6. T. thiooxidans and $T$. ferrooxidans are mesophiles (like the other species cited above), growing best at temperatures ranging from 25 to $35^{\circ} \mathrm{C}$. T. thiooxidans utilizes inorganic sulfur as a source of energy, whereas $T$. ferrooxidans can utilize $\mathrm{Fe}^{2+}$ in addition to sulfur as a sole source of energy. If there is a strain of either of these two species that can be cultivated in conventional batch culture with glucose in lieu of sulfur or 
iron, it remains to be described adequately. Strains of $T$. ferrooxidans that have been claimed to grow with glucose in lieu of $\mathrm{Fe}^{2+}$ have been shown to be contaminated with extraneous microorganisms $(1,3,7)$.

The thermophilic iron-oxidizing bacteria that have been isolated from copper mine leaching dumps (2), which are acidophilic, chemolithotrophic heterotrophs, require an organic supplement in order to grow at $55^{\circ} \mathrm{C}$. Ferrous iron serves as a source of energy, and the organic compound fulfills a particular carbon requirement (14).

The acidophilic, facultative autotroph Thiobacillus acidophilus was named and described by Guay and Silver (3). This species was discovered as a contaminant in an allegedly pure culture of $T$. ferrooxidans strain TM. Although $T$. acidophilus grows autotrophically with elemental sulfur as a sole source of energy and $\mathrm{CO}_{2}$ as the source of carbon, it grows equally well with glucose as the source of energy in the absence of sulfur. This organism is not able to utilize $\mathrm{Fe}^{2+}$ as a source of energy.

Acidophilic, obligate chemoorganotrophs have been encountered in the same environments that harbor acidophilic thiobacilli. One species, Acidiphilium cryptum (5), has been isolated from allegedly pure cultures of $T$. ferrooxidans $(6,7)$. Unlike T. acidophilus of Guay and Silver, another contaminant in cultures of $T$. ferrooxidans, A. cryptum is not able to utilize inorganic sulfur (or $\mathrm{Fe}^{2+}$ ) as a source of energy in laboratory media, either with or without organic supplements. However, in this paper I demonstrate that in yeast extract this species can oxidize sulfur gratuitously, with neither its growth rate nor its cell yield affected by sulfur oxidation. Thus, although it is not a thiobacillus, $A$. cryptum nevertheless may be involved in mineral leaching in acidic mineral environments. Numerous gram-negative, acidophilic chemoorganotrophs physiologically similar to $A$. cryptum were isolated from acidic mine water and were examined extensively by Wichlacz and Unz (22), but these bacteria have not been named.

In this paper I summarize and extend the previous descriptions of mixotrophic species of Thiobacillus. The deoxyribonucleic acid (DNA) analyses described here are the beginning of a study of the relationships among these and other bacteria. In addition, species status is accorded Thiobacillus sp. strain $\mathrm{A}^{\mathrm{T}}$ (type strain), and the name Thiobacillus acidophilus, which was not included on the Approved Lists of Bacterial Names (16), is revived.

\section{MATERIALS AND METHODS}

Bacterial strains and maintenance of bacteria. The strains used in this study are listed in Table 1.T. acidophilus and $A$. cryptum strains were maintained on agar slants stored at $5^{\circ} \mathrm{C}$ for 1 month between transfers. The maintenance medium used was basal salts medium 1 supplemented with $1 \mathrm{~g}$ of glucose per liter, $0.1 \mathrm{~g}$ of Trypticase soy per liter, and $12 \mathrm{~g}$ of agar per liter. (Double-strength agar and sugar were autoclaved separately and were added to double-strength basal salts solution [pH 3] after the solutions had cooled to $45^{\circ} \mathrm{C}$.) $T$. ferrooxidans strain $\mathrm{m}-1$ was maintained in liquid ferrous sulfate medium (6) at $5^{\circ} \mathrm{C}$ for 3 weeks between transfers. The other thiobacilli were maintained on solidified Trypticase soy-glucose (TSG) medium slants at $\mathrm{pH} 6.9$ or on solidified basal salts medium 1 (pH 6.9) supplemented with $0.5 \mathrm{~g}$ of $\mathrm{Na}_{2} \mathrm{~S}_{2} \mathrm{O}_{3} \cdot 5 \mathrm{H}_{2} \mathrm{O}$ per liter.

Media. Two mineral salts solutions were used to prepare the growth media. Basal salts solution 1 contained (per liter) $2 \mathrm{~g}$ of $\left(\mathrm{NH}_{4}\right)_{2} \mathrm{SO}_{4}, 0.5 \mathrm{~g}$ of $\mathrm{K}_{2} \mathrm{HPO}_{4}$, and $0.5 \mathrm{~g}$ of $\mathrm{MgSO}_{4} \cdot 7 \mathrm{H}_{2} \mathrm{O}$. Basal salts solution 2 contained (per liter) $0.4 \mathrm{~g}$ of $\mathrm{NH}_{4} \mathrm{Cl}, 0.2 \mathrm{~g}$ of $\mathrm{K}_{2} \mathrm{HPO}_{4}, 0.2 \mathrm{~g}$ of $\mathrm{KH}_{2} \mathrm{PO}_{4}, 0.4 \mathrm{~g}$ of $\mathrm{MgSO}_{4} \cdot 7 \mathrm{H}_{2} \mathrm{O}$, and $0.3 \mathrm{ml}$ of a trace element solution (21). The $\mathrm{pH}$ of each solution was adjusted with $1 \mathrm{~N}_{2} \mathrm{HO}_{4}$ and $\mathrm{NaOH}$. The basal salts solutions were autoclaved at $121^{\circ} \mathrm{C}$ for $15 \mathrm{~min}$, either as 10 -ml volumes in test tubes $(17-\mathrm{mm}$ internal diameter by $150 \mathrm{~mm})$ or as $100-\mathrm{ml}$ volumes in 500-ml Erlenmeyer flasks. Various supplements were added to the basal salts solutions and were either autoclaved together with the salts solutions or sterilized separately (if required) at $\mathbf{1 0}$ times the desired final concentration and added to the sterile, cooled basal salts solutions. The following supplements were used, individually and in mixtures, as the experiments required: Trypticase soy broth (dehydrated; BBL Microbiology Systems, Cockeysville, Md.), $0.1 \mathrm{~g} /$ /iter; yeast extract (dehydrated; BBL), 0.1 to 1 $\mathrm{g} /$ liter; $\mathrm{Na}_{2} \mathrm{~S}_{2} \mathrm{O}_{3} \cdot 5 \mathrm{H}_{2} \mathrm{O}, 5 \mathrm{~g} /$ liter; glucose, $1 \mathrm{~g} /$ liter; mannitol, $1 \mathrm{~g} / \mathrm{liter}$; and powdered sulfur (sublimed sulfur; type S-591 Fisher Scientific Co., Pittsburgh, $\mathrm{Pa}$.), $10 \mathrm{~g}$ /liter. Sulfur was added to the basal salts solutions and sterilized at $105^{\circ} \mathrm{C}$ (to prevent melting) for $1 \mathrm{~h}$ on 2 successive days. TSG medium contained (per liter) $3 \mathbf{g}$ of Trypticase soy broth (dehydrated; BBL), $1 \mathrm{~g}$ of glucose, and $2 \mathrm{~g}$ of $\mathrm{K}_{2} \mathrm{HPO}_{4}$; the $\mathrm{pH}$ was adjusted to 7 . If needed, media were solidified with 12 $\mathrm{g}$ of agar per liter.

To obtain the $10^{12}$ cells required for DNA extraction, each culture was grown in 10 liters of appropriate medium in a 23-liter carboy with forced aeration at $28^{\circ} \mathrm{C}$. Mannitol medium (Table 1) contained $10 \mathrm{~g}$ of mannitol (reagent grade) in 10 liters of basal salts medium 1 . Glucose medium (Table 1) contained $10 \mathrm{~g}$ of glucose (reagent grade) in 10 liters of basal salts medium 2. Thiosulfate medium (Table 1) contained 100 $\mathrm{g}$ of $\mathrm{Na}_{2} \mathrm{~S}_{2} \mathrm{O}_{3} \cdot 5 \mathrm{H}_{2} \mathrm{O}$ in 10 liters of basal salts medium 2 . Media in carboys were autoclaved at $121^{\circ} \mathrm{C}$ for $1 \mathrm{~h}$. Sulfur and ferrous sulfate media (Table 1) contained, respectively, $100 \mathrm{~g}$ of powdered sulfur and $400 \mathrm{~g}$ of $\mathrm{FeSO}_{4} \cdot 7 \mathrm{H}_{2} \mathrm{O}$, each in 10 liters of basal salts, and were prepared as described previously (6).

Assays for growth. Cell counts were made microscopically by using a Petroff-Hausser bacterial counting chamber. A Coleman model 9 Nepho-colorimeter was used to measure growth photometrically and was calibrated for measuring the cell masses of thiobacilli (dry weight) with known weights of cells, a procedure described previously (8). Solidified medium in petri 
TABLE 1. DNA homologies among and DNA base compositions of strains of Thiobacillus and Acidiphilium

\begin{tabular}{|c|c|c|c|c|c|c|c|c|c|}
\hline \multirow[b]{2}{*}{ Test strain ${ }^{\alpha}$} & \multirow[b]{2}{*}{$\begin{array}{l}\text { Energy } \\
\text { source }^{b}\end{array}$} & \multirow{2}{*}{$\begin{array}{c}\mathrm{G}+\mathrm{C} \\
\text { content } \\
\text { of DNA } \\
(\mathrm{mol} \%)^{r}\end{array}$} & \multicolumn{7}{|c|}{ \% Homology to reference DNA from strain: ${ }^{d}$} \\
\hline & & & $\begin{array}{l}7 \mathrm{p} \\
(\mathrm{M})^{e}\end{array}$ & $\begin{array}{l}\mathbf{m}-1 \\
(\mathrm{Fe})\end{array}$ & $\begin{array}{c}\text { ATCC } \\
23370 \\
\text { (Th) }\end{array}$ & $\begin{array}{c}\text { ATCC } \\
15466 \\
\text { (Th) }\end{array}$ & $\begin{array}{c}\text { ATCC } \\
8093 \\
\text { (TSG) }\end{array}$ & $\begin{array}{c}\text { ATCC } \\
25364 \\
\text { (TSG) }\end{array}$ & $\begin{array}{c}\text { ATCC } \\
33463 \\
\text { (G) }\end{array}$ \\
\hline \multirow[t]{2}{*}{ T. acidophilus 7p } & $\mathbf{M}$ & $63-64$ & 100 & 0 & $\mathbf{0}$ & $\mathbf{0}$ & $\mathbf{0}$ & 0 & 7 \\
\hline & $\mathbf{S}$ & & 105 & $\mathbf{0}$ & 0 & $\mathbf{0}$ & $\mathbf{0}$ & $\mathbf{0}$ & \\
\hline T. acidophilus DSM 700R & $\mathbf{G}$ & & 91 & & & & & & 9 \\
\hline T. thioparus ATCC 8158 & Th & 63 & 8 & 0 & 0 & $\mathbf{0}$ & 12 & & $\mathbf{0}$ \\
\hline T. thioparus ATCC 23646 & Th & 65 & $\mathbf{0}$ & 0 & 0 & $\mathbf{0}$ & $\mathbf{0}$ & 10 & $\mathbf{0}$ \\
\hline T. ferrooxidans $\mathrm{m}-1$ & $\mathbf{F e}$ & 65 & $\mathbf{0}$ & 100 & ${ }^{*} 0$ & 10 & & & $\mathbf{0}$ \\
\hline \multirow[t]{2}{*}{ T. perometabolis ATCC 23370} & Th & 66 & $\mathbf{0}$ & 0 & 100 & 78 & $\mathbf{0}$ & 11 & $\mathbf{0}$ \\
\hline & TSG & 66 & $\mathbf{0}$ & 0 & 95 & 69 & $\mathbf{0}$ & 6 & \\
\hline \multirow[t]{2}{*}{ T. intermedius ATCC 15466} & Th & 67 & $\mathbf{0}$ & 0 & 56 & 100 & $\mathbf{0}$ & 11 & $\mathbf{0}$ \\
\hline & TSG & 67 & 0 & 0 & 51 & 105 & 12 & 7 & \\
\hline \multirow[t]{2}{*}{ T. novellus ATCC 8093} & Th & 68 & & & 0 & 8 & 100 & $\mathbf{0}$ & \\
\hline & TSG & 68 & 16 & 8 & 0 & 7 & 100 & 0 & $\mathbf{0}$ \\
\hline $\begin{array}{l}\text { Thiobacillus sp. strain } \mathrm{A2}^{\mathrm{T}} \\
\left.\text { (= ATCC } 25364^{\mathrm{T}}\right)\end{array}$ & TSG & 68 & $\mathbf{0}$ & $\mathbf{0}$ & $\mathbf{0}$ & $\mathbf{0}$ & 0 & 100 & $\mathbf{0}$ \\
\hline $\begin{array}{l}\text { A. cryptum Lhet } 2 \\
\text { (= ATCC 33463) }\end{array}$ & $\mathbf{G}$ & 70 & 14 & & 0 & & 7 & 0 & 100 \\
\hline A. cryptum $\mathrm{T} 21$ & $\mathbf{G}$ & 69 & 26 & & & & & & 88 \\
\hline
\end{tabular}

${ }^{a} T$. acidophilus $7 p$ is a single-colony isolate from strain 7 (= ATCC 27807) of Guay and Silver (3). Strain 7 was obtained from O. Tuovinen, and strain DSM 700 was obtained from H. Hippe of the Deutsche Sammlung von Mikroorganismen. This strain was sent to the German collection by R. Guay. $T$. ferrooxidans $m-1$ (4) and $A$. cryptum Lhet2 (= ATCC 33463) were isolated in my laboratory (5, 7). Strain T21 was kindly supplied by J. A. Antheunisse, who received it from Arkesteyn and de Bont (1). The other strains were acquired from the American Type Culture Collection.

$b$ The DNAs were extracted from cultures in media containing the following energy sources: mannitol (M), powdered sulfur (S), glucose (G), thiosulfate (Th), ferrous iron (Fe), and TSG. See text for the compositions of these media.

' Except for $T$. acidophilus, the $G+C$ contents were determined by the melting point method (see text). The value for $T$. acidophilus was taken from reference 3 . The results of assays performed in other laboratories are as follows: $T$. acidophilus 7p, 63.5 mol\%, determined by reverse-phase, high-pressure liquid chromatography of enzymatically hydrolyzed DNA supplied by me from a glucose-grown culture (Gehrke et al., personal communication); $T$. thioparus, 62 to $66 \mathrm{~mol} \%$, determined by buoyant density (9); $T$. ferrooxidans $\mathrm{m}-1,65.3$ mol\%, determined by buoyant density with DNA supplied by me (M. Mandel, personal communication); $T$. perometabolis, 67.9 mol\%, determined by buoyant density (Mandel, personal communication); $T$. novellus, 68 mol\%, determined by buoyant density (19); Thiobacillus sp. strain $\mathrm{A} 2^{\mathrm{T}}, 65$ to $68 \mathrm{~mol} \%$, determined by buoyant density (19); A cryptum Lhet $2,69.4 \mathrm{~mol} \%$, determined by buoyant density with DNA supplied by me (Mandel, personal communication).

$d$ The reference DNAs were radiolabeled with tritium (see text).

e Energy source of the culture from which the DNA was extracted. M, Mannitol; Fe, ferrous iron; Th, thiosulfate; $G$, glucose.

plates was used to monitor the purity of cultures and also to determine the viable cell population.

Analyses of DNA. The guanine-plus-cytosine $(\mathrm{G}+\mathrm{C})$ contents of DNAs were determined by the melting point method described previously (6). The $G+C$ values shown in Table 1 are arithmetic means from at least two assays. The $\mathbf{G}+\mathbf{C}$ content was determined for DNA from a particular strain cultivated with different energy sources to aid in confirming the purity of the cultures.

DNA homologies were determined by the previously described S1 method (6), which is based on the procedure of Johnson et al. (11). The reannealing temperature in most instances was $70^{\circ} \mathrm{C}$. To simplify comprehension of Table 1, homology values of $6 \%$ or less are recorded as zero homology. My interpretation of the results followed the suggestion of Johnson (10), namely, that DNA from a test strain (Table 1) having $\leq \mathbf{2 0 \%}$ homology to DNA from a reference strain (Table 1) indicates that the test strain belongs to a species that is not related to the reference strain. Test DNA having 20 to $50 \%$ homology to reference DNA indicates that the test strain belongs to a species different from, although closely related to, the species of the reference strain. Test DNA having 50 to $70 \%$ homology to reference DNA indicates that the test strain is related to the reference strain at the subspecies level. Test DNA having $\geq 70 \%$ homology to reference DNA indicates that the test strain may be considered a member of the same species as the reference strain. These homology ranges have been derived from experience with several bacterial groups through correlations with phenotype (10) and serve as approximations to establish relatedness at the species level.

For the bacteria listed in Table 1, experiments in 


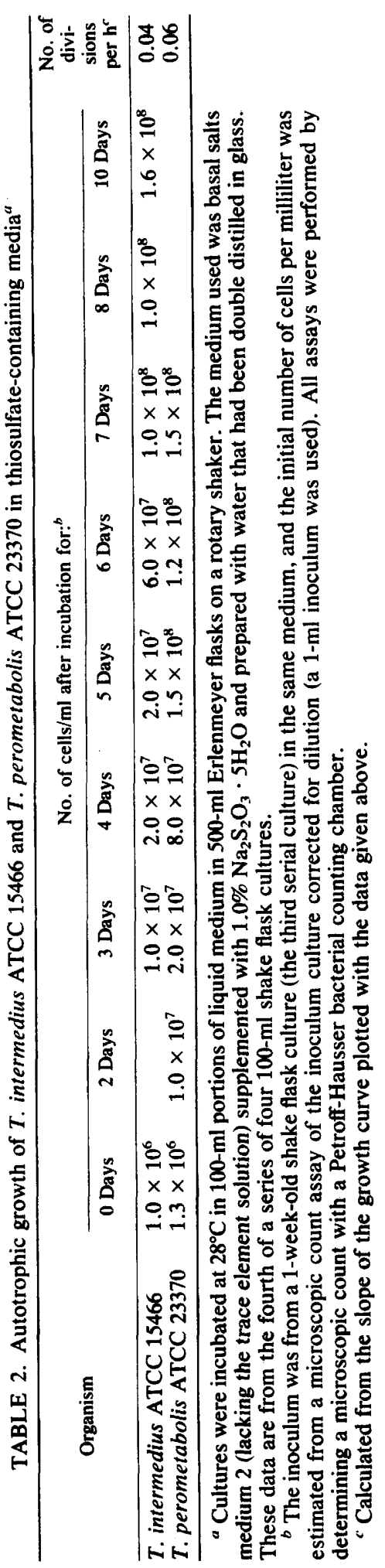

which replicate samples of the same DNA or samples of DNA from the same strain cultivated in different media were used resulted in homology values of $\geq 90 \%$ compared with reference DNA from the same strain. Therefore, a homology value of $90 \%$ suggests, but does not prove, identity at the clonal level. The precision of the method in the high range of homology $(\geq 90 \%)$ is $\sim 5$ to $8 \%$ homology. Therefore, strains differing by only one or a few genes cannot be distinguished by means of DNA homology.

\section{RESULTS AND DISCUSSION}

In Table 1 the strains used in this study are listed in order of increasing $\mathrm{G}+\mathrm{C}$ content. $T$. thioparus and $T$. ferrooxidans, which are not phenotypically related to the other species, were included because their $\mathrm{G}+\mathrm{C}$ contents fall in the same range. As anticipated, these species showed negligible homology with mixotrophic thiobacilli and with the chemoorganotrophic species $A$. cryptum.

London and Rittenberg (13) noted that $T$. perometabolis and $T$. intermedius are similar in phenotype, but concluded that these two organisms "differ enough in specific metabolic characteristics to make it unlikely that the new isolate is a laboratory artifact, a chance mutant of $T$. intermedius . . . "The accuracy of this insight is supported by the homology results shown in Table 1. If the two organisms differ by one or a few mutations, their DNAs should show nearly $100 \%$ homology (within the experimental precision of the method used, which is $\sim 5$ to $8 \%$ homology). However, data in Table 1 do indicate a close relationship. Based on findings obtained with other bacteria (10), these organisms are related at least at the subspecific level.

As originally described (13), $T$. perometabolis did not grow autotrophically with thiosulfate. However, this organism does possess potential for autotrophic growth. By using a heavy inoculum, an autotrophic variant was acquired. This variant was cultivated through four successive 1 -ml transfers in $100 \mathrm{ml}$ of thiosulfate medium (Table 2) (at least 28 cell generations). Thiosulfate-adapted $T$. perometabolis ATCC 23370 grew at a somewhat faster rate than $T$. intermedius ATCC 15466 (Table 2), and these two organisms are phenotypically distinct. For example, thiosulfate-adapted $T$. perometabolis ATCC 23370 grows well when it is inoculated into TSG medium or yeast extract-glucose medium, whereas $T$. intermedius ATCC 15466 grows poorly in these media unless thiosulfate is added. Neither strain grows when it is inoculated into organic media at $\mathrm{pH} \leq 3$ (Table 3 ). However, once growth has begun at a higher $\mathrm{pH}$ in medium containing thiosulfate, catabolic activity can reduce the $\mathrm{pH}$ below 2.5 (12).

Taylor and Hoare (19) compared T. novellus and Thiobacillus sp. strain $\mathrm{A2}^{\mathrm{T}}$ and concluded 
TABLE 3. Phenotypic traits of thiobacilli and A. cryptum

\begin{tabular}{|c|c|c|c|c|c|c|c|c|c|c|c|c|c|}
\hline \multirow{2}{*}{ Organism } & \multicolumn{10}{|c|}{$\begin{array}{l}\text { Growth in yeast extract-glucose medium at the } \\
\text { following pH values }{ }^{a}\end{array}$} & \multirow{2}{*}{$\begin{array}{l}\text { Growth } \\
\text { with } \\
\text { powdered } \\
\text { sulfur as } \\
\text { the sole } \\
\text { source of } \\
\text { energy }^{b}\end{array}$} & \multirow{2}{*}{$\begin{array}{l}\text { Growth } \\
\text { with } \\
\text { thiosulfate } \\
\text { as the sole } \\
\text { source of } \\
\text { energy }^{b}\end{array}$} & \multirow{2}{*}{$\begin{array}{l}\text { Growth } \\
\text { with other } \\
\text { substrate }^{c}\end{array}$} \\
\hline & 2.1 & 3.0 & 3.8 & 4.9 & 5.5 & 5.8 & 6.3 & 7.3 & 8.2 & 8.8 & & & \\
\hline $\begin{array}{l}\text { T. acidophilus } 7 \mathrm{p} \\
\text { T. perometabolis } \\
\text { ATCC } 23370\end{array}$ & $\begin{array}{l}+^{d} \\
-\end{array}$ & $\begin{array}{l}+ \\
-\end{array}$ & $\begin{array}{l}+ \\
+\end{array}$ & $\begin{array}{l}+ \\
+\end{array}$ & $\begin{array}{l}+ \\
+\end{array}$ & $\begin{array}{l} \pm \\
+\end{array}$ & $\overline{+}$ & $\overline{+}$ & - & - & $\begin{array}{l}+ \\
\pm\end{array}$ & $\pm^{e}$ & \\
\hline $\begin{array}{l}\text { T. intermedius } \\
\text { ATCC } 15466\end{array}$ & - & - & - & $+f$ & $+^{f}$ & $+^{f}$ & $+^{f}$ & $+^{f}$ & $+^{f}$ & - & +8 & + & \\
\hline T. novellus ATCC 8093 & - & - & - & - & + & + & + & + & + & + & -8 & + & - \\
\hline $\begin{array}{l}\text { Thiobacillus sp. strain } \mathrm{A}^{\mathrm{T}} \\
\quad\left(=\mathrm{ATCC} 25364^{\mathrm{T}}\right)\end{array}$ & - & - & - & - & $t^{h}$ & $t^{h}$ & $+h$ & + & + & + & $-i$ & + & + \\
\hline $\begin{array}{l}\text { A. cryptum Lhet } 2 \\
\text { (= ATCC } 33463 \text { ) }\end{array}$ & + & + & + & + & + & + & - & - & - & - & - & - & \\
\hline
\end{tabular}

${ }^{a}$ Organisms were grown in 100 -ml portions of basal salts medium containing $0.05 \%$ (wt/vol) yeast extract and $0.1 \%(w t / v o l)$ glucose in $500-\mathrm{ml}$ Erlenmeyer flasks on a rotary shaker at $28^{\circ} \mathrm{C}$. Flasks inoculated with $T$. intermedius ATCC 15466 were supplemented with $0.5 \%$ (wt/vol) $\mathrm{Na}_{2} \mathrm{~S}_{2} \mathrm{O}_{3} \cdot 5 \mathrm{H}_{2} \mathrm{O}$ to improve the growth of this organism.

${ }_{b}$ Organisms were grown in $100-\mathrm{ml}$ portions of basal salts medium containing $1 \%(\mathrm{wt} / \mathrm{vol})$ powdered sulfur or $0.5 \%$ (wt/vol) $\mathrm{Na}_{2} \mathrm{~S}_{2} \mathrm{O}_{3} \cdot 5 \mathrm{H}_{2} \mathrm{O}$ in 500 -ml Erlenmeyer flasks and incubated on a rotary shaker at $28^{\circ} \mathrm{C}$.

${ }^{c}$ Data from Taylor and Hoare (19). The substrates tested were sucrose, $n$-butanol, butyrate, L-leucine, Lisoleucine, L-glutamate, L-aspartate, malate, succinate, and cyclohexane carboxylate. These compounds were the only organic nutrients in the culture medium.

$d+$, Good growth; - , no growth; \pm , poor growth or variable results.

' London and Rittenberg (13), reported that $T$. perometabolis was not able to grow autotrophically in thiosulfate. However, using a large initial inoculum, I adapted this species to grow at least as well as $T$. intermedius when thiosulfate was used as the sole energy source.

$f$ Once growth started in media containing thiosulfate, catabolism of the thiosulfate caused the pH to drop to approximately 2.5 , but growth could not be initiated in this medium at a pH of about 4 .

${ }^{8}$ Data from London (12).

${ }^{h}$ The cells grew as large spheres (spheroplasts), but appeared normal at $\mathbf{p H} \geq 6.8$.

$i$ Data from Taylor and Hoare (19).

that it was possible that these two organisms belong to the same species. However, phenotypically these two organisms are as distinct as most currently recognized species of Thiobacillus. The homology data (Table 1) confirm distinctiveness at the genomic level.

Ideally, before an organism is reported as belonging to a new, undescribed species, several strains of the taxon from various sources should be isolated, described, and compared. However, no simple procedure that preferentially selects for mixotrophic bacteria has been devised, and the discovery of these bacteria has been fortuitous. For this reason new species of mixotrophs have been recognized and described on the basis of single, chance isolates. A species is no less valid or important merely because a convenient procedure for its selective isolation is unavailable. Thiobacillus sp. strain $\mathrm{A} 2^{\mathrm{T}}$ was discovered by chance 14 years ago (19), and no isolate with a similar phenotype has been described to date. In fact, the phenotypic characterization of this strain is an example of descriptive rigor (19). The metabolic diversity and robustness of Thiobacillus sp. strain $\mathrm{A}^{\mathrm{T}}{ }^{\mathrm{T}}$ suggest wide distribution.
Therefore, the name Thiobacillus versutus is proposed for this organism. Derivation of the specific epithet and a formal description of this species are given below.

$T$. acidophilus and A. cryptum are acidophilic. (Complete descriptions of these species have been given by Guay and Silver [3] and Harrison [5], respectively.) The former grows equally well with either elemental sulfur or glucose as an energy source $(3,7)$. A. cryptum, on the other hand, cannot utilize sulfur as an energy source, with or without an organic supplement (5). These two species are genomically distinct (Table 1).

In earlier studies with $A$. cryptum, basal salts medium 2 supplemented with $0.01 \%$ Trypticase soy and $0.1 \%$ glucose was used. Langworthy (personal communication) found that $A$. cryptum grows faster and attains a higher cell population in yeast extract than in Trypticase soy. Therefore, $A$. cryptum was cultivated in yeast extract medium for comparison. This experiment showed that the cell yield was proportional to the concentration of yeast extract throughout the range from 0.01 to $0.1 \%$. Culture lag was at a 
minimum and the growth rate was at a maximum (ca. 0.05 division per $\mathrm{h}$ ) at yeast extract concentrations of 0.02 to $0.04 \%$. Acid was formed when sulfur was present, presumably because of sulfur oxidation. This activity, however, was gratuitous since it did not increase the growth rate or improve the cell yield (Table 4). In contrast, $T$. acidophilus utilized sulfur as a sole source of energy, and the addition of sulfur to the yeast extract medium increased the cell yield above the yield attainable in the yeast extract medium alone (at a yield-limiting concentration of yeast extract) (Table 4). The growth of $T$. acidophilus with sulfur slowed down as the $\mathrm{pH}$ dropped to about 2 . However, neutralizing the acid permitted growth to continue.

From T. ferrooxidans ATCC 13598, Arkesteyn and de Bont (1) isolated acidophilic contaminants which they assumed to be $T$. acidophilus. (A. cryptum had not been described at the time of their study.) One strain (strain T21) from their laboratory was examined (Table 1). This strain is a strain of $A$. cryptum and may be identical to strain 13598het, which has been described previously (7) and which was isolated from the same source. Thus, workers in two laboratories have independently demonstrated that $T$. ferrooxidans ATCC 13598 is contaminated with an extraneous chemoorganotroph.

$T$. acidophilus was described and named by Guay and Silver (3), but this name does not appear on the Approved Lists of Bacterial Names (16). Accordingly, this name is here revived.

In summary, $T$. perometabolis ATCC 23370 and $T$. intermedius ATCC 15466 are physiologically similar, differing only slightly. This similarity has been confirmed by DNA homology stud- ies, which demonstrate that the former organism is related to the latter at the subspecific level. On the basis of phenotype and DNA homology data, Thiobacillus sp. strain $\mathrm{A2}^{\mathrm{T}}$ of Taylor and Hoare (19) is clearly a distinct Thiobacillus. Accordingly, the name Thiobacillus versutus sp. nov. (ver. su'tus. L. adj. versutus versatile) is proposed for this organism. Strain A2 (= ATCC 25364) is designated the type strain. The following description of this species and of the type strain is taken largely from Taylor and Hoare (19).

$T$. versutus is an aerobic, mesophilic, gramnegative, nonsporulating, nonmotile, rodshaped, non-acidophilic mixotroph. The $\mathrm{G}+\mathrm{C}$ content of its DNA is approximately $68 \mathrm{~mol} \%$. It grows well in mineral salts medium with thiosulfate as the sole energy source, and it grows optimally between $\mathrm{pH} 7$ and 9 . This organism grows anaerobically in the presence of nitrate as an electron acceptor and produces copious $\mathrm{N}_{2}$ with organic substrates, but not with thiosulfate in mineral salts medium. In yeast extract-glucose medium the growth rate is optimum between $\mathrm{pH} 7$ and 9; growth is less rapid between $\mathrm{pH} 5.5$ and 6.5, and the cells may become bloated; growth does not occur in this medium at $\mathrm{pH}<5$. T. versutus can be differentiated from other non-acidophilic mixotrophic thiobacilli by its rapid rate of growth and cell yield in thiosulfate and organic media, by its denitrifying activity with organic substrates, and by its versatility in utilizing various organic compounds as sole sources of energy. The following compounds are utilized by $T$. versutus but not by $T$. novellus as sole energy sources: sucrose, butyrate, $n$-butyl alcohol, L-leucine, L-isoleucine, L-tryptophan, DL-serine, L-glutamate, $\mathrm{L}$-asparate, malate, succinate, citrate, benzoate, $p$-hydroxybenzoate,

TABLE 4. Growth of $T$. acidophilus DSM 700R and A. cryptum ATCC 33463 with and without elemental sulfur ${ }^{a}$

\begin{tabular}{|c|c|c|c|c|c|}
\hline Organism & Medium $^{b}$ & $\begin{array}{l}\text { Initial no. of } \\
\text { cells } / \mathrm{ml}^{c}\end{array}$ & $\underset{\mathrm{pH}}{\text { Initial }}$ & $\begin{array}{l}\text { Final no. of cells } / \\
\mathrm{ml}^{d}\end{array}$ & Final $\mathrm{pH}^{e}$ \\
\hline \multirow[t]{3}{*}{ T. acidophilus DSM 700R } & $\mathbf{Y}$ & $1 \times 10^{6}$ & 4.1 & $8.0 \pm 0.2 \times 10^{7}$ & 5.2 \\
\hline & $\mathbf{Y}+\mathbf{S}$ & $1 \times 10^{6}$ & 4.1 & $2.4 \pm 0.2 \times 10^{8}$ & 1.7 \\
\hline & $S$ & $1 \times 10^{6}$ & 3.9 & $2.2 \pm 0.2 \times 10^{8}$ & 1.7 \\
\hline \multirow[t]{3}{*}{ A. cryptum Lhet2 ( $=$ ATCC 33463$)$} & $\mathbf{Y}$ & $1 \times 10^{6}$ & 4.1 & $2.0 \pm 0.2 \times 10^{8}$ & 5.7 \\
\hline & $\mathbf{Y}+\mathbf{S}$ & $1 \times 10^{6}$ & 4.1 & $2.0 \pm 0.2 \times 10^{8}$ & 3.0 \\
\hline & $\mathbf{S}$ & $1 \times 10^{6}$ & 3.9 & $<5 \times 10^{6}$ & 3.6 \\
\hline
\end{tabular}

${ }^{a}$ Cultures were incubated for 2 weeks at $28^{\circ} \mathrm{C}$ in $100-\mathrm{ml}$ portions of liquid medium in $500-\mathrm{ml}$ Erlenmeyer flasks on a rotary shaker.

$b$ The medium used was basal salts medium 1 supplemented with $0.02 \%$ yeast extract (Y) or $1 \%$ sublimed sulfur (S) or both.

$c$ The inocula (ca. $0.5 \mathrm{ml}$ ) were from shake flask cultures in basal salts medium 1 supplemented with $0.02 \%$ yeast extract and $0.1 \%$ glucose.

$d$ These cell yields, which were determined by microscopic counting, were attained within 1 week and remained unchanged during the second week of incubation (see text) $\left(2 \times 10^{8}\right.$ cells is equivalent to $44 \pm 4 \mu \mathrm{g}$ [dry weight]).

The pH of uninoculated (control) flasks did not change during the 2-week test period (i.e., the final pH was the same as the initial $\mathrm{pH}$ ). 
$m$-hydroxybenzoate, $p$-aminobenzoate, and cyclohexane carboxylate.

T. acidophilus of Guay and Silver (3) is a distinctive facultative autotroph. Since this name also does not appear on the Approved Lists of Bacterial Names (16), it is revived here. A description of this organism, taken primarily from Guay and Silver (3), follows.

Thiobacillus acidophilus nom. rev. (a.ci. do'phi.lus. L. adj. acidus sour; M. L. neut. n. acidum acid; Gr. adj. philus loving; M. L. adj. acidophilus acid loving). T. acidophilus is an aerobic, mesophilic, gram-negative, nonsporulating, motile or nonmotile, rod-shaped, acidophilic, facultative autotroph. The $\mathrm{G}+\mathrm{C}$ content of its DNA is 63 to $64 \mathrm{~mol} \%$. It grows equally well in mineral salts medium with either elemental sulfur or glucose as the sole source of energy. It cannot use $\mathrm{Fe}^{2+}$ as a sole source of energy. Optimum growth in media containing these substances occurs between $\mathrm{pH} 2$ and 4.5. Little if any growth occurs at $\mathrm{pH} \geq 6$. A variety of organic compounds can serve as sources of energy in a mineral salts medium; these include D-glucose, D-fructose, D-galactose, D-mannitol, $\mathrm{D}$-xylose, D-ribose, L-arabinose, sucrose, citrate, malate, DL-aspartate, and DL-glutamate. The type strain is strain ATCC 27807. The description of the type strain is the same as that given above for the species.

\section{ACKNOWLEDGMENTS}

I thank H. Hippe of the Deutsche Sammlung von Mikroorganismen for suggestions and cultures and Theodore A. Tarkow for devising the specific epithet for Thiobacillus versutus.

This research was aided by a Research Fellowship awarded by the University of Missouri Research Council.

\section{LITERATURE CITED}

1. Arkesteyn, G. J. M. W., and J. A. M. de Bont. 1980. Thiobacillus acidophilus: a study of its presence in Thiobacillus ferrooxidans cultures. Can. J. Microbiol. 26:1057-1065.

2. Brierley, J. A. 1978. Thermophilic iron-oxidizing bacteria found in copper leaching dumps. Appl. Environ. Microbiol. 36:523-525.

3. Guay, R., and M. Silver. 1975. Thiobacillus acidophilus sp. nov.; isolation and some physiological characteristics. Can. J. Microbiol. 21:281-288.

4. Harrison, A. P., Jr. 1978. Microbial succession and min- eral leaching in an artificial coal spoil. Appl. Environ. Microbiol. 36:861-869.

5. Harrison, A. P., Jr. 1981. Acidiphilium cryptum gen. nov., sp. nov., heterotrophic bacterium from acidic mineral environments. Int. J. Syst. Bacteriol. 31:327-332.

6. Harrison, A. P., Jr. 1982 . Genomic and physiological diversity amongst strains of Thiobacillus ferrooxidans, and genomic comparison with Thiobacillus thiooxidans. Arch. Microbiol. 131:68-76.

7. Harrison, A. P., Jr., B. W. Jarvis, and J. L. Johnson. 1980. Heterotrophic bacteria from cultures of autotrophic Thiobacillus ferrooxidans: relationships as studied by means of deoxyribonucleic acid homology. J. Bacteriol. 143:448-454.

8. Harrison, A. P., Jr., and F. R. Lawrence. 1963. Phenotypic, genotypic, and chemical changes in starving populations of Aerobacter aerogenes. J. Bacteriol. 85:742-750.

9. Jackson, J. F., D. J. W. Moriarty, and D. J. D. Nicholas. 1968. Deoxyribonucleic acid base composition and taxonomy of thiobacilli and some nitrifying bacteria. J. Gen. Microbiol. 53:53-60.

10. Johnson, J. L. 1973. Use of nucleic acid homologies in the taxonomy of anaerobic bacteria. Int. J. Syst. Bacteriol. 23:308-315.

11. Johnson, J. L., C. F. Phelps, C. S. Cummins, J. London, and F. Gasser. 1980. Taxonomy of the Lactobacillus acidophilus group. Int. J. Syst. Bacteriol. 30:53-68.

12. London, J. 1963. Thiobacillus intermedius nov. sp., a novel type of facultative autotroph. Arch. Microbiol. 46:329-337.

13. London, J., and S. C. Rittenberg. 1967. Thiobacillus perometabolis nov. sp., a non-autotrophic Thiobacillus. Arch. Microbiol. 59:218-225.

14. Norris, P. R., J. A. Brierley, and D. P. Kelly. 1980 . Physiological characteristics of two facultatively thermophilic mineral-oxidizing bacteria. FEMS Microbiol. Lett. 7:119122.

15. Rittenberg, S. C. 1969 . The role of exogenous organic matter in the physiology of chemolithotrophic bacteria. Adv. Microbiol. Physiol. 3:159-196.

16. Skerman, V. B. D., V. McGowan, and P. H. A. Sneath (ed.). 1980. Approved lists of bacterial names. Int. J. Syst. Bacteriol. 30:225-420.

17. Starkey, R. L. 1934. Cultivation of organisms concerned in the oxidation of thiosulfate. J. Bacteriol. 28:365-386.

18. Starkey, R. L. 1935. Isolation of some bacteria which oxidize thiosulfate. Soil. Sci. 39:197-215.

19. Taylor, B. F., and D. S. Hoare. 1969. New facultative Thiobacillus and a reevaluation of the heterotrophic potential of Thiobacillus novellus. J. Bacteriol. 100:487-497.

20. Vishniac, W. V. 1974. Genus Thiobacillus p. 456-461. In R. E. Buchanan and N. E. Gibbons (ed.), Bergey's manual of determinative bacteriology, 8 th ed. The Williams \& Wilkins Co., Baltimore.

21. Vishniac, W. V., and M. Santer. 1957. The thiobacilli. Bacteriol. Rev. 21:195-213.

22. Wichlacz, P. L., and R. F. Unz. 1981. Acidophilic, heterotrophic bacteria of acidic mine waters. Appl. Environ. Microbiol. 41:1254-1261. 